\title{
REVIEW: MEKANISME EKSTRAK SELEDRI (Apium Graveolens L) SEBAGAI ANTIHIPERTENSI
}

\author{
Qarriy 'Aina Urfiyya \\ Program Studi DIII Farmasi, Akademi Farmasi Indonesia Yogyakarta \\ email: qarriyainaurfiyya@afi.ac.id \\ *Corresponding author
}

\begin{abstract}
Abstrak
Hipertensi merupakan penyebab utama kematian dini di dunia. Hasil RISKESDAS 2018 menunjukkan prevalensi hipertensi di Indonesia, usia diatas 18 tahun sebesar 34,11\%. Seledri merupakan tanaman yang memiliki aktivitas sebagai antihipertensi, dengan kandungan flavonoid. Tujuan dari penelitian ini untuk merangkum mekanisme ekstrak seledri (Apium graveolens L) sebagai antihipertensi pada beberapa artikel ilmiah. Metode yang digunakan pada review artikel ini yaitu dengan melakukan studi literatur pada artikel ilmiah yang dipublikasi tahun 2006 - 2021. Terdapat 5 artikel yang sesuai dan dilakukan review. Hasil review artikel menunjukkan ekstrak seledri memiliki aktivitas menurunkan tekanan darah, melalui mekanisme stimulasi reseptor muskarinik, diuretik dan vasodilator.
\end{abstract}

Kata kunci: Seledri, Apium graveolens L, Hipertensi, Vasodilator

\begin{abstract}
Hypertension is the leading cause of premature death in the world. Report on the results of the 2018 Basic Health Research, the prevalence of hypertension in Indonesia, aged over 18 years is $34.11 \%$. Celery is a plant that has antihypertensive activity, with flavonoid content. The purpose of this study was to summarize the mechanism of celery extract (Apium graveolens L) as an antihypertensive in several scientific articles. The method used in this article review was to conduct a literature study on scientific articles published in 2006 - 2021. The results of this review articles show that celery extract has activity in lowering blood pressure, through the mechanism of stimulation of muscarinic receptors, diuretics and vasodilators.
\end{abstract}

Keywords: Celery, Apium graveolens L, Hypertension, Vasodilator

\section{PENDAHULUAN}

Hipertensi atau tekanan darah tinggi merupakan penyakit yang serius yang secara signifikan dapat meningkatkan resiko penyakit jantung, ginjal, otak dan lainnya. Diperkirakan 1,28 miliar orang di seluruh dunia, usia 30-79 tahun menderita hipertensi, dan $46 \%$ tidak menyadari memiliki kondisi tersebut. Jumlah orang yang terdiagnosa hipertensi dan melakukan pengobatan dibawah $42 \%$, dan hanya $21 \%$ dengan tekanan 
darah terkontrol (World Health Organization, 2021). Laporan hasil Riset Kesehatan Dasar Tahun 2018, prevalensi hipertensi di Indonesia, usia diatas 18 tahun sebesar 34,11\% (Kementrian Kesehatan RI, 2018). Hipertensi merupakan penyebab utama kematian dini di dunia, sehingga salah satu target global penyakit tidak menular adalah menurunkan prevalensi hipertensi sebesar 33\% pada tahun 2010 - 2030 (World Health Organization, 2021).

Menurut data RISKESDAS 2018, sebanyak 4,5\% masyarakat yang telah menderita hipertensi tidak rutin konsumsi obat hipertensi karena tidak tahan dengan efek samping obat yang. Beberapa efek samping dari agen farmakologis antihipertensi seperti hipotensi, hipotensi ortostatik, berkurangnya toleransi glukosa, peningkatan kolesterol plasma dan disfungsi seksual (Chatterjea dan Rana, 2011). Manifestasi klinis hipotensi seperti pusing, pandangan buram, mual dan muntah, lemas hingga sesak nafas (American Heart Association, 2016), hipotensi ortostatik dapat ditegakkan apabila terdapat penurunan tekanan darah sistolik $>20 \mathrm{mmHg}$ atau tekanan darah diastolik $>10 \mathrm{mmHg}$ ketika pasien dalam posisi berdiri (Low dan Tomalia, 2015). Karena banyaknya efek samping obat tersebut, sekarang mulai banyak dikembangkan pemanfaatan bahan herbal untuk membantu pengobatan hipertensi, yang memiliki efek terapi dan efek samping minimal. WHO memperkirakan bahwa $80 \%$ masyarakat di Asia dan Afrika bergantung pada pengobatan tradisional untuk perawatan kesehatan primer. Bagian tanaman yang digunakan mulai dari bunga, daun, batang, buah serta akar tumbuhan yang memiliki kandungan zat kimia yang berguna untuk mencegah, meredakan atau mengobati penyakit (World Health Organization, 2021).

Tanaman herbal yang dapat digunakan sebagai antihipertensi adalah seledri (Apium graveolens L.), famili Umbelliferae (Shanmugapriya dan Ushadevi, 2015). Tanaman ini memiliki aktivitas sebagai antibakteri, antijamur, antiinflamasi, antioksidan, antelmintik, antispasmodik, karminatif, diuretik, pencahar dan obat penenang (Kooti dkk, 2014). Penelitian sebelumnya menunjukkan efek antihipertensi dari seledri pada hewan uji tikus (Sohrabi dkk, 2021; Brankovi dkk, 2010; Moghadam dkk, 2013). Penelitian di manusia juga menunjukkan adanya efek penurunan tekanan darah pada pasien lansia (Siantar dkk, 2021; Saputra dan Triola, 2016).

Seledri memiliki banyak konstituen, salah satunya adalah n-butylphthalide (NBP) yang menyediakan aroma dan rasa seledri (Sowbhagya, 2014). Beberapa peneliti membuktikan efek antihipertensi dari NBP pada hewan uji (Zhu dkk, 2015; Sohrabi dkk, 2021; Moghadam dkk, 2013). Kandungan seledri diantaranya flavonoid apiin, apigenin, saponin, tanin, minyak atsiri, fitosterol, kolin, lipase, pthalide, asparagin, alkaloid dan vitamin A/B dan C (Saputra dan Triola, 2016). Apium graveolens (Seledri) merupakan salah satu tanaman yang kaya akan kandungan flavonoid seperti apigenin dan apiin (Kooti dkk, 2014). Seledri dikenal sebagai diuretik lemah, antiseptik kemih, antispasmodik, obat cacing dan obat penenang (Kooti dkk, 2014). Komponen fitokimia dalam seledri dapat menurunkan aktivitas sitokin pro inflamasi dan mencegah peradangan. Flavonoid dalam seledri juga dapat menekan peradangan kardiovaskular. Kandungan phthalides pada seledri menyebabkan perluasan otot polos di pembuluh darah dan dapat menurunkan tekanan darah (Hedayati dkk, 2019). Mekanisme seledri dalam menurunkan tekanan darah telah dikaji dalam beberapa studi. Sehingga, tujuan dari penelitian ini untuk merangkum mekanisme ekstrak seledri (Apium graveolens $\mathrm{L}$ ) sebagai antihipertensi pada beberapa artikel ilmiah. 


\section{METODE PENELITIAN}

Metode yang digunakan pada review artikel ini yaitu dengan melakukan studi literatur. Studi literatur diseleksi berdasarkan kriteria, artikel yang diterbitkan tahun 2006 - 2021, artikel yang menggunakan Bahasa Inggris atau Bahasa Indonesia, artikel full text, merupakan uji pra klinik (subyek uji adalah hewan). Pencarian artikel menggunakan beberapa kombinasi kata kunci untuk mendapatkan artikel sesuai kriteria, pada database google scholar, Pubmed dan sciencedirect. Kata kunci yang digunakan adalah, "Hypertension", "Blood Pressure", "Hypotensive", "Apium Graveolens", "Celery", "Extract", "Mechanisms". Tahapan proses pencarian literatur ditampilkan pada Bagan 1.

\begin{tabular}{|c|c|}
\hline Google scholar (127 artikel), pubmed (15 artikel), sciencedirect (15 artikel). N=157 artikel \\
\hline Setelah eksklusi duplikasi (n=149 artikel) \\
\hline $\begin{array}{c}8 \text { artikel yang sama pada } \\
\text { beberapa database dieksklusi }\end{array}$ \\
\hline 9 judul relevan dilakukan review \\
\hline $\begin{array}{c}140 \text { artikel dieksklusi karena judul } \\
\text { tidak sesuai tema, merupakan review } \\
\text { dan bahasa tidak sesuai }\end{array}$ \\
\hline 5 artikel dilakukan review. Google scholar (3 artikel), pubmed (1 artikel), sciencedirect \\
(1 artikel) \\
$\begin{array}{c}4 \text { artikel dieksklusi : } 1 \text { artikel } \\
\text { merupakan uji klinik, } 1 \text { artikel } \\
\text { menggunakan sediaan jus, } 2 \text { artikel } \\
\text { tidak membahas mekanisme seledri }\end{array}$ \\
\hline
\end{tabular}

Bagan 1. Tahapan Proses Pencarian Pustaka

\section{HASIL DAN PEMBAHASAN}

Seledri memiliki beberapa bagian yang memiliki aktivitas farmakologi, salah satunya adalah biji seledri. Biji seledri mengandung zat aktif kimia yang bertanggungjawab atas aroma minyak biji seledri, yaitu sedanolide, 3-n-butyl phthalide, dan sedanenolide (3-n-butyl-4-5- dihydrophthalide) (Dianat dkk, 2015). Penelitian Moghadam dkk (2013) melakukan pengukuran senyawa 3-n-butylphthalid (NBP) pada ekstrak heksan, metanol dan hidro-alkohol biji seledri. Konsentrasi kandungan 3-nbutylphthalid 4 kali lebih tinggi pada ekstrak heksan dibandingkan dengan kedua ekstrak lainnya (Moghadam dkk, 2013). Penelitian Tashakori-Sabzevar dkk (2016) juga meneliti kandungan NBP pada ekstrak biji seledri. Kandungan NBP ekstrak heksan lebih tinggi dibandingkan ekstrak hidroalkohol, dikarenakan NBP merupakan senyawa berminyak yang larut didalam lemak, dan memiliki kelarutan lebih tinggi dalam pelarut non polar (Wu dkk, 2015). 
Efek ekstrak biji seledri terhadap tekanan darah dan denyut jantung juga telah diteliti. Penelitian Tashakori-Sabzevar dkk (2016), ekstrak heksan biji seledri 12,5 $\mathrm{mg} / \mathrm{kgBB}$ memiliki efek penurunan tekanan darah dan penurunan denyut jantung (Tashakori-Sabzevar dkk, 2016). Efek ini sama dengan kerja beta blocker dengan cara memperlambat denyut jantung, sehingga menurunkan tekanan darah (Oparil dkk, 2019).

Menurut penelitian lain, ekstrak heksan biji seledri $300 \mathrm{mg} / \mathrm{kgBB}$ memiliki efek penurunan tekanan darah dan peningkatan denyut jantung yang signifikan dibandingkan dengan kontrol dan ekstrak lainnya (Moghadam dkk, 2013). Hasil serupa ditunjukkan oleh penelitian Jorge dkk (2013), bahwa terjadi efek peningkatan denyut jantung pemberian ekstrak heksan biji seledri $300 \mathrm{mg} / \mathrm{kgBB}$ (Jorge dkk, 2013). Apabila terjadi penurunan tekanan darah, akan terjadi mekanisme kompensasi oleh tubuh. Ketika curah jantung menurun, resistensi perifer meningkat melalui penyempitan arteriol terminal untuk menurunkan kaliber pembuluh darah, untuk mempertahankan tekanan darah. Ketika resistensi perifer menurun, curah jantung akan meningkat melalui peningkatan denyut jantung untuk mempertahankan tekanan darah (Sharma dan Hashmi, 2021). Efek vasodilatasi mungkin terlibat dalam efek hipotensi dan peningkatan denyut jantung komponen ekstrak biji seledri (3-n-butylphthalid) (Moghadam dkk, 2013).

Brankovi dkk (2010) meneliti efek hipotensif ekstrak air dan etanol konsentrasi $15 \mathrm{mg} / \mathrm{kgBB}$ tanaman seledri. Rata-rata penurunan tekanan darah ekstrak air seledri lebih besar dibandingkan dengan ekstrak etanol. Durasi efek hipotensi yang ditimbulkan tergantung dengan dosis yang diberikan, semakin besar dosis ekstrak, semakin lama durasi efek hipotensi (Brankovi dkk, 2010). Tanaman herbal memiliki aktivitas penurunan tekanan darah dapat melalui beberapa mekanisme, diantaranya mempengaruhi sel otot polos pembuluh darah, fungsi endotel, aktivasi platelet, sinyal pro inflamasi dan ekspresi gen (Al-Disi dkk, 2016). Mekanisme seledri dalam menurunkan tekanan darah telah dipelajari pada beberapa penelitian. Rangkuman mekanisme dan efek hipotensif seledri ditampilkan pada Tabel 1.

Tabel 1. Rangkuman Efek Hipotensi dan Mekanisme Ekstrak Seledri

\begin{tabular}{|c|c|c|c|c|c|}
\hline $\begin{array}{c}\text { Bagian } \\
\text { Tanaman }\end{array}$ & $\begin{array}{c}\text { Model } \\
\text { Penelitian }\end{array}$ & Parameter & Hasil & $\begin{array}{c}\text { Mekanism } \\
\text { e }\end{array}$ & Referensi \\
\hline Seledri & $\begin{array}{l}\text { Atrium Tikus } \\
\text { (in vitro) dan } \\
\text { Kelinci (in } \\
\text { vivo) }\end{array}$ & $\begin{array}{l}\% \text { Rata-rata } \\
\text { penurunan } \\
\text { tekanan darah }\end{array}$ & $\begin{array}{l}\text { Efek hipotensif, } \\
\text { inotropik negatif } \\
\text { dan kronotropik } \\
\text { negatif }\end{array}$ & $\begin{array}{l}\text { Stimulasi } \\
\text { reseptor } \\
\text { muskarinik }\end{array}$ & $\begin{array}{l}\text { (Brankovi } \\
\text { dkk, 2010) }\end{array}$ \\
\hline $\begin{array}{l}\text { Biji seledri } \\
\text { (3-n- } \\
\text { butylphthal } \\
\text { id) }\end{array}$ & Tikus (in vivo) & $\begin{array}{l}\text { Tekanan darah } \\
\text { dan } \\
\text { denyut jantung }\end{array}$ & Efek hipotensif & $\begin{array}{l}\text { Diuretik } \\
\text { dan } \\
\text { vasodilator }\end{array}$ & $\begin{array}{l}\text { (Moghada } \\
\text { m dkk, } \\
2013)\end{array}$ \\
\hline $\begin{array}{l}\text { Biji seledri } \\
\text { (3-n- } \\
\text { butylphthal } \\
\text { id) }\end{array}$ & $\begin{array}{l}\text { Tikus (in } \\
\text { vivo), aorta } \\
\text { torak tikus (in } \\
\text { vitro) }\end{array}$ & $\begin{array}{l}\text { Tekanan darah, } \\
\text { denyut jantung, } \\
\text { rata-rata tekanan } \\
\text { darah arteri }\end{array}$ & $\begin{array}{l}\text { Efek hipotensif, } \\
\text { dan bradikardi }\end{array}$ & $\begin{array}{l}\text { Vasodilato } \\
\mathrm{r}\end{array}$ & $\begin{array}{l}\text { (Tashakori } \\
\text {-Sabzevar } \\
\text { dkk, 2016) }\end{array}$ \\
\hline Seledri & $\begin{array}{l}\text { Cincin aorta } \\
\text { tikus (in vitro) }\end{array}$ & $\mathrm{EC}_{50}$ & $\begin{array}{l}\text { Efek } \\
\text { vasorelaksan }\end{array}$ & $\begin{array}{l}\text { Vasorelaks } \\
\text { an }\end{array}$ & $\begin{array}{l}\text { (Jorge dkk, } \\
2013)\end{array}$ \\
\hline Biji seledri & $\begin{array}{l}\text { Aorta tikus } \\
\text { (in vitro) }\end{array}$ & $\mathrm{EC}_{50}$ & $\begin{array}{l}\text { Efek } \\
\text { vasorelaksan }\end{array}$ & $\begin{array}{l}\text { Vasorelaks } \\
\text { an }\end{array}$ & $\begin{array}{l}\text { (Sohrabi } \\
\text { dkk, 2021) }\end{array}$ \\
\hline
\end{tabular}




\section{Stimulasi Reseptor Muskarinik}

Penelitian Brankovi dkk (2010) pada hewan uji tikus, pemberian ekstrak air dan etanol seledri dapat menurunkan dan menghambat tingkat kontraksi atrium, menunjukkan adanya efek inotropik dan kronotropik negative ekstrak seledri (Brankovi dkk, 2010). Penelitian Radenković dkk (2013) juga menunjukkan efek inotropik negatif dan kronotropik negatif akut dari ekstrak seledri (Radenković dkk, 2013). Penelitian (Tashakori-Sabzevar dkk, 2016) ekstrak heksan biji seledri memberikan efek hipotensi dan bradikardia (penurunan denyut jantung), menjelaskan efek inotropik dan kronotropik negatif ekstrak biji seledri melalui bloking kanal $\mathrm{Ca}^{2+}$ di otot jantung (TashakoriSabzevar dkk, 2016).

Untuk mengevaluasi mekanisme efek hipotensi ekstrak seledri, peneliti menggunakan atropin yang merupakan antagonis non selektif reseptor muskarinik. Pemberian atropin dapat memblokir sebagian respon hipotensif dari ekstrak air maupun etanol seledri. Blokade parsial dari atropin ini mengindikasikan adanya peran komponen kolinergik pada efek hipotensi ekstrak seledri, melalui stimulasi reseptor muskarinik (Brankovi dkk, 2010). Reseptor Muskarinik M3 memiliki peran utama sebagai vasodilator yang diinduksi oleh asetilkolin pada pembuluh darah (Attinà dkk, 2008).

\section{Diuretik}

Penelitian Moghadam dkk (2013) mengevaluasi efek diuretik ekstrak biji seledri. Efek diuretik dilihat dari pengamatan volume urin. Volume urin tikus pada kelompok ekstrak heksan lebih banyak dibandingkan dengan ekstrak air-etanol, ekstrak metanol dan kontrol positif spironolakton, sehingga efek diuretik menjadi salah satu kemungkinan mekanisme antihipertensi dari ekstrak biji seledri (Moghadam dkk, 2013).

\section{Vasodilator}

Penelitian Tashakori-Sabzevar dkk (2016), ekstrak heksan biji seledri dapat menghambat vasokonstriksi yang diinduksi fenilefrin dan $\mathrm{KCl}$ pada aorta tikus. Penelitian lain, ekstrak biji seledri juga dapat menyebabkan relaksasi pada cincin aorta tikus yang diinduksi oleh fenilefrin dan KCL (Sohrabi dkk, 2021). Fenilefrin merupakan Agonis alfa-adrenoreseptor yang dapat menginduksi kontraksi aorta dengan masuknya kalsium ekstraseluler melalui kanal $\mathrm{Ca}^{2+}$ yang diperantarai reseptor dan pelepasan $\mathrm{Ca}^{2+}$ intraseluler dari retikulum sarkoplasma (Niazmand dkk, 2014). Inkubasi cincin aorta dengan indometasin (inhibitor siklooksigenase) tidak mengubah respon relaksasi yang disebabkan oleh ekstrak biji seledri. Hasil tersebut menunjukkan bahwa kandungan aktif dalam ekstrak heksan biji seledri mungkin tidak memberikan efek relaksasi melalui jalur siklooksigenase dan produksi prostasiklin (Tashakori-Sabzevar dkk, 2016). Hasil serupa juga ditunjukkan pada penelitian Sohrabi dkk (2021), perlakuan cincin aorta dengan indometasin atau L-NAME, tidak mencegah efek vasorelaksan ekstrak biji seledri. Hasil ini menunjukkan bahwa jalur endotel mungkin terlibat dalam efek vasorelaksan dari biji seledri (Sohrabi dkk, 2021).

Nitrit Oksida (NO) berperan dalam vasodilatasi. Inkubasi aorta tikus dengan LNAME (inhibitor nitrit oksida sintase non selektif), (Bremen dkk, 2013) dapat mengurangi efek vasodilatasi ekstrak terutama pada konsentrasi yang lebih rendah. Meskipun mekanisme lain mungkin terlibat, hasil penelitian tersebut menunjukkan bahwa Nitrit Oksida Sintase (NOS) berperan dalam efek vasodilatasi senyawa aktif NBP biji seledri. Hasil tersebut menegaskan adanya jalur vasodilatasi non-endotel, seperti penghambatan masuknya $\mathrm{Ca}^{2+}$ ke otot polos (Tashakori-Sabzevar dkk, 2016).

Terdapat dua kanal $\mathrm{Ca}^{2+}$ pada sel otot polos, yaitu kanal $\mathrm{Ca}^{2+}$ tergantung voltase dan kanal $\mathrm{Ca}^{2+}$ yang diperantarai reseptor. Induktor vasokontriksi $\mathrm{KCL}$ menyebabkan terjadinya depolarisasi membrane dan peningkatan influks $\mathrm{Ca}^{2+}$ melalui kanal tergantung voltase, sedangkan norepinefrin menyebabkan pelepasan $\mathrm{Ca}^{2+}$ intraseluler melalui kanal 
retikulum $\mathrm{Ca}^{2+}$ sarkoplasma yang diaktivasi oleh reseptor $\mathrm{IP}_{3}$ (Cunha dkk, 2013; Zhu $\mathrm{dkk}, 2007)$. Influks $\mathrm{Ca}^{2+}$ ekstraseluler dapat melalui kanal $\mathrm{Ca}^{2+}$ tergantung voltase, kanal $\mathrm{Ca}^{2+}$ diperantarai reseptor serta pelepasan $\mathrm{Ca}^{2+}$ dari retikulum sarkoplasma dengan cara aktivasi inositol triphosphate (IP3) dan ryanodine receptors (RYR) (Martinsen dkk, 2014). Agen yang bekerja pada sel otot polos dapat mengubah tonus melalui 3 mekanisme, yaitu perubahan konsentrasi ion $\mathrm{Ca}^{2+}$ intraseluler, variasi sensitivitas regulator kontraktif pengatur kanal $\mathrm{Ca}^{2+}$ dan modulasi sensitifitas input vasoaktif lainnya (Jorge dkk, 2010).

Jorge dkk (2013) meneliti efek vasodilator dari beberapa macam ekstrak seledri. Ekstrak heksan, diklorometan, etil asetat dan metanol, namun efek relaksasi pada cincin aorta tikus signifikan lebih besar pada ekstrak etil asetat. Untuk mengevaluasi mekanisme vasodilator ekstrak melalui kanal kalsium, dilakukan penambahan KCL dan norepinefrin sebagai induksi kontraksi. Ekstrak etil asetat seledri memberikan respon penghambatan maksimal terhadap kontraksi (Jorge dkk, 2013). Ekstrak etil asetat menghambat respon kontraksi dari norepinefrin dan $\mathrm{CaCl}_{2}$, menunjukkan kemungkinan penghambatan kanal $\mathrm{Ca}^{2+}$ tergantung voltase dan kanal $\mathrm{Ca}^{2+}$ diperantarai reseptor (Jorge dkk, 2013).

Efek ekstrak biji seledri terhadap aliran $\mathrm{Ca}^{2+}$ dalam sel otot polos pembuluh darah dievaluasi. Hasilnya menunjukkan bahwa biji seledri secara signifikan menurunkan kontraksi yang disebabkan oleh penambahan $\mathrm{Ca}^{2+}$ ekstraseluler pada cincin aorta tikus yang diinduksi PE dan KCL. Ini menunjukkan bahwa biji seledri dapat menghambat reseptor ryanodine dan/atau jalur IP3 dan menurunkan konsentrasi $\mathrm{Ca}^{2+}$ intraseluler, mengurangi aktivitas rantai ringan myosin melalui jalur dependen DAG-PKC (diacylglycerol- protein kinase C), dan menurunkan $\mathrm{Ca}^{2+}$ intraseluler melalui pemblokiran kanal $\mathrm{Ca}^{2+}$ diperantarai reseptor dan relaksasi aorta. Penghambatan kanal $\mathrm{Ca}^{2+}$ diperantarai reseptor oleh ekstrak biji seledri mungkin merupakan mekanisme utama dalam relaksasi aorta, karena ekstrak biji seledri menurunkan kontraksi aorta yang diinduksi oleh PE dengan penambahan $\mathrm{Ca}^{2+}$ (Sohrabi dkk, 2021).

Keluarnya ion $\mathrm{K}^{+}$menyebabkan hiperpolarisasi membran dan menurunkan influks $\mathrm{Ca}^{2+}$, sehingga terjadi efek vasorelaksasi. Beberapa jenis dari kanal $\mathrm{K}^{+}$seperti, kanal kalium sensitive ATP, kanal kalium non selektif dan kanal kalium tergantung voltase. Penelitian Sohrabi dkk (2021) menunjukkan bahwa 4-AP (penghambat kanal kalium tergantung voltase) mengurangi efek relaksasi ekstrak biji seledri dan mengurangi potensi relaksasi, ini menunjukkan keterlibatan kanal kalium tergantung voltase dalam efek vasorelaksan ekstrak biji seledri (Sohrabi dkk, 2021). Penelitian Sohrabi dkk (2021) menunjukkan ekstrak biji seledri memiliki efek vasorelaksan. Mekanisme vasorelaksasi yang mungkin terlibat meliputi penghambatan kanal kalsium diperantarai reseptor, kanal kalsium tergantung voltase, pelepasan faktor hiperpolarisasi endotel dan aktivasi kanal kalium tergantung voltase (Sohrabi dkk, 2021).

Penelitian lainnya juga mempelajari efek vasodilator dari tanaman seledri. Penelitian Anjos dkk (2013) menemukan efek vasodilatasi pada arteri mesenterika tikus yang terisolasi dengan adanya zat aktif linalool dalam biji seledri (Anjos dkk, 2013). FenFang dkk (2007) mempelajari mekanisme vasodilatasi jus seledri dan mendapatkan kemungkinan adanya penghambatan kanal kalsium diperantarai reseptor di otot polos (Fen-Fang dkk, 2007). Penelitian lain menyebutkan adanya efek relaksan yang ditimbulkan oleh senyawa aktif seledri seperti apigenin, luteolin, kaempferol, asam caffeat, asam ferrulat dan asam kumarat (Yao dkk, 2010).

\section{KESIMPULAN}

Ekstrak seledri (biji dan herba) memiliki efek menurunkan tekanan darah melalui mekanisme stimulasi reseptor muskarinik, diuretik dan vasodilator. Mekanisme 
vasodilatasi ekstrak seledri melalui jalur endotel dan non endotel, dengan penghambatan kanal kalsium (kanal kalsium diperantarai reseptor, kanal kalsium tergantung voltase) dan aktivasi kanal kalium.

\section{REFERENSI}

Al Disi, S. S., Anwar, M. A., \& Eid, A. H. (2016). Anti-hypertensive herbs and their mechanisms of action: Part I. Frontiers in Pharmacology, 6(JAN), 1-24. https://doi.org/10.3389/fphar.2015.00323

American Heart Association. (2016). Low Blood Pressure - When Blood Pressure is Too Low.

Anjos, P. J. C., Lima, A. O., Cunha, P. S., De Sousa, D. P., Onofre, A. S. C., Ribeiro, T. P., Medeiros, I. A., Antoniolli, Â. R., Quintans-Júnior, L. J., \& Santos, M. R. V. (2013). Cardiovascular effects induced by linalool in normotensive and hypertensive rats. Zeitschrift Fur Naturforschung - Section C Journal of Biosciences, 68 C(5-6), 181-190. https://doi.org/10.1515/znc-2013-5-603

Attinà, T. M., Oliver, J. J., Malatino, L. S., \& Webb, D. J. (2008). Contribution of the M3 muscarinic receptors to the vasodilator response to acetylcholine in the human forearm vascular bed. British Journal of Clinical Pharmacology, 66(2), 300-303. https://doi.org/10.1111/j.1365-2125.2008.03194.x

B, Sowbhagya, H. (2014). Chemistry, Technology, and Nutraceutical Functions of Celery (Apium graveolens L.): An Overview. Critical Reviews in Food Science and Nutrition, 3(54), 389-398.

Brankovi, S., Radenkovi, M., Veljkovi, S., Kosti, M., Miladinovi, B., \& Pavlovi, D. (2010). Hypotensive and Cardioinhibotory Effects of the Aqueous and Ethanol Extracts of Celery ( Apium Graveolens, Apiaceae ). Acta Medica Medianae, 49(1), $13-16$.

Chatterjea, M, N \& Rana, S. (2011). Textbook of medical biochemistry. Wife Goes On.

Cunha, G. H. da, Moraes, M. O. de, Fechine, F. V., Frota Bezerra, F. A. Ô., Silveira, E. R., Canuto, K. M., \& Moraes, M. E. A. de. (2013). Vasorelaxant and antihypertensive effects of methanolic fraction of the essential oil of Alpinia zerumbet. Vascular Pharmacology, 58(5-6), 337-345. https://doi.org/10.1016/j.vph.2013.04.001

Delivery, S. (2017). Do not distribute without permission from WHO R-Draft WHO guidelines for comments. March, 1-60.

Dianat, M., Veisi, A., Ahangarpour, A., \& Fathi Moghaddam, H. (2015). The effect of hydro-alcoholic celery (Apiumgraveolens) leaf extract on cardiovascular parameters and lipid profile in animal model of hypertension induced by fructose. Avicenna Journal of Phytomedicine, 5(3), 203-209. https://doi.org/10.22038/ajp.2015.3839

Fen-Fang, Tang; Guo Jun-xia; Jing, Zhang; Jing, Li; Meng, S.-Q. (2007). Study on Hypotensive and Vasodilatory Effects of Celery Juice. Food Science.

Hedayati, N., Bemani Naeini, M., Mohammadinejad, A., \& Mohajeri, S. A. (2019). Beneficial effects of celery (Apium graveolens) on metabolic syndrome: A review of the existing evidences. Phytotherapy Research, 33(12), 3040-3053. https://doi.org/10.1002/ptr.6492

Jorge, V. G., Ángel, J. R. L., Adrián, T. S., Francisco, A. C., Anuar, S. G., Samuel, E. S., Ángel, S. O., \& Emmanuel, H. N. (2013). Vasorelaxant activity of extracts obtained from Apium graveolens: Possible source for vasorelaxant molecules isolation with potential antihypertensive effect. Asian Pacific Journal of Tropical Biomedicine, 
3(10), 776-779. https://doi.org/10.1016/S2221-1691(13)60154-9

Kooti, W., Ali-Akbari, S., Asadi-Samani, M., Ghadery, H., \& Ashtary-Larky, D. (2014). A Review on Medicinal Plant of Apium graveolens. Advance Herbal Medicina, $1(1), 48-59$.

Laporan Nasional Riset Kesehatan. (2018). Laporan_Nasional_RKD2018_FINAL.pdf. In Badan Penelitian dan Pengembangan Kesehatan (p. 198). http://labdata.litbang.kemkes.go.id/images/download/laporan/RKD/2018/Laporan_ Nasional_RKD2018_FINAL.pdf

Low, PA. \& Tomalia, VA. (2015). Orthostatic Hypotension: Mechanisms, Causes, Management. Journal of Clinical Neurology, 11(3), pp. 220-226.

Martinsen, A., Dessy, C., \& Morel, N. (2014). Regulation of calcium channels in smooth muscle: New insights into the role of myosin light chain kinase. Channels, 8(5), 402-413. https://doi.org/10.4161/19336950.2014.950537

Moghadam, M. H., Imenshahidi, M., \& Mohajeri, S. A. (2013). Antihypertensive effect of celery seed on rat blood pressure in chronic administration. Journal of Medicinal Food, 16(6), 558-563. https://doi.org/10.1089/jmf.2012.2664

Niazmand, S., Fereidouni, E., Mahmoudabady, M., \& Mousavi, S. M. (2014). Endothelium-independent vasorelaxant effects of hydroalcoholic extract from nigella sativa seed in rat aorta: The roles of $\mathrm{Ca} 2+$ and $\mathrm{K}+$ channels. BioMed Research International, 2014. https://doi.org/10.1155/2014/247054

Oparil, S., Acelajado, M. C., Bakris, G. L., Berlowitz, D. R., Cífková, R., Dominiczak, A. F., Grassi, G., Jordan, J., Poulter, N. R., Rodgers, A., \& Whelton, P. K. (2019). HHS Public Access. Hypertension. Nature Reviews Disease Primers, 22(4), 1-48. https://doi.org/10.1038/nrdp.2018.14.Hypertension

Radenković, M., Kitić, D., Kostić, M., Mrkaić, A., Pavlović, D., Miladinović, B., \& Branković, S. (2013). Effects of extracts of ginkgo, onion, and celery on the contractility of isolated rat Atria. Clinical and Experimental Hypertension, 35(8), 595-600. https://doi.org/10.3109/10641963.2013.776566

Saputra, O., \& Fitria, T. (2016). Khasiat Daun Seledri ( Apium graveolens ) Terhadap Tekanan Darah Tinggi Pada Pasien Hiperkolestrolemia. Majority, 5(April), 1-6.

Shanmugapriya, R., Ushadevi, T. (2015). Phytochemical screening and GC-MS analysis of Apium Graveolens L. seed extracts. International Journal of Pharma and Bio Sciences, 6(2).

Sharma S, Hashmi MF, B. P. (2021). Hypotension. StatPearls Publishing. https://www.ncbi.nlm.nih.gov/books/NBK499961/

Siantar, R. L., Simanjuntak, F. M., \& Aritonang, T. R. (2021). Efectiveness of Celery ( Apium Graveolens ) on Hppertension in The Elderly. Midwifery Iocs Publisher, 9(1), 360-365.

Sohrabi, F., Niazmand, S., Mahmoudabady, M., \& Niazmand, M. J. (2021). The vasodilatory effect of Apium graveolens L (celery) seed in isolated rat aorta: The roles of endothelium, calcium and potassium channels. Avicenna Journal of Phytomedicine, 11(1), 44-53. https://doi.org/10.22038/AJP.2020.15697

Tashakori-Sabzevar, F., Razavi, B. M., Imenshahidi, M., Daneshmandi, M., Fatehi, H., Sarkarizi, Y. E., \& Mohajeri, S. A. (2016). Evaluation of mechanism for antihypertensive and vasorelaxant effects of hexanic and hydroalcoholic extracts of celery seed in normotensive and hypertensive rats. Revista Brasileira de Farmacognosia, 26(5), 619-626. https://doi.org/10.1016/j.bjp.2016.05.012

van Bremen, T., Drömann, D., Luitjens, K., Dodt, C., Dalhoff, K., Goldmann, T., \& Schaaf, B. (2013). Triggering receptor expressed on myeloid cells - 1 (Trem-1) on blood neutrophils is associated with cytokine inducibility in human E. coli sepsis. 
Diagnostic Pathology, 8(1), 1-8. https://doi.org/10.1186/1746-1596-8-24

Vergara-Galicia, J., Ortiz-Andrade, R., Rivera-Leyva, J., Castillo-España, P., VillalobosMolina, R., Ibarra-Barajas, M., Gallardo-Ortiz, I., \& Estrada-Soto, S. (2010). Vasorelaxant and antihypertensive effects of methanolic extract from roots of Laelia anceps are mediated by calcium-channel antagonism. Fitoterapia, 81(5), 350-357. https://doi.org/10.1016/j.fitote.2009.10.009

World Health Organization. (2021). Hypertension. World Health Organization. https://www.who.int/news-room/fact-sheets/detail/hypertension

Wu, X., Li, Y., Xu, D., Zhou, H., Wang, J., Guo, X., \& Zhang, Y. (2015). Gas Chromatography-Mass spectrometry and High-Performance liquid chromotagraphy analysis of the drug absorption characteristics in the buccal mucosa via a circulating device. Biomedical Reports, 3(1), 51-54. https://doi.org/10.3892/br.2014.382

Yao, Y., Sang, W., Zhou, M., \& Ren, G. (2010). Phenolic composition and antioxidant activities of 11 celery cultivars. Journal of Food Science, 75(1), 9-13. https://doi.org/10.1111/j.1750-3841.2009.01392.x

Zhu, J. U. N., Zhang, Y., \& Yang, C. (2015). Protective effect of 3-n-butylphthalide against hypertensive nephropathy in spontaneously hypertensive rats. 1448-1454. https://doi.org/10.3892/mmr.2014.2791

Zhu, X. M., Fang, L. H., Li, Y. J., \& Du, G. H. (2007). Endothelium-dependent and independent relaxation induced by pinocembrin in rat aortic rings. Vascular Pharmacology, 46(3), 160-165. https://doi.org/10.1016/j.vph.2006.09.003. 